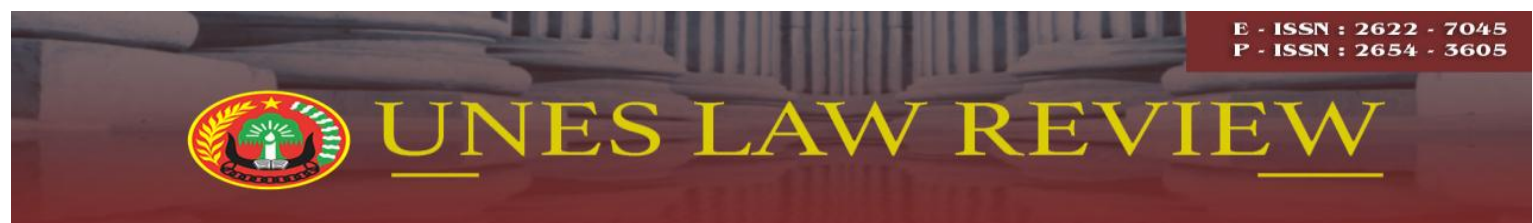

Email: uneslawreview@gmail.com

Online: http://review-unes.com/index.php/law

Volume 2, Issue 3, Maret 2020

\title{
PELAKSANAAN PEMBINAAN DAN PENGAWASAN \\ TERHADAP PEJABAT PEMBUAT AKTA TANAH DALAM PENDAFTARAN HAK ATAS TANAH DI KOTA PAYAKUMBUH
}

\author{
Eka Marwahyuni Wira \\ Program Magister Ilmu Hukum, Universitas Ekasakti, Padang, Indonesia \\ Email : ekamarwahyuni01@gmail.com
}

\begin{abstract}
Land Deed Making Officials (hereinafter referred to as PPAT) are general officials who assist the National Land Agency to carry out some of the land registration activities. Article 1 number 1 Government Regulation No. 37 of 1998 concerning Regulations of Position of the Acting Officer for Land Deed states that the PPAT is authorized to make authentic deeds concerning certain legal actions regarding land rights or Ownership Rights in Flats. In carrying out his position PPAT is required to be thorough, careful, orderly and understand the regulations relating to land. In practice, PPAT in carrying out its duties and authorities often makes mistakes both administratively and legally. The results of research and analysis show that the implementation of guidance and supervision of the PPAT in the registration of land rights in Payakumbuh City, carried out by the National Land Agency through the socialization of regulations relating to the PPAT-n, making the deed, making monthly reports, checking the list of books deed, examination of the results of the binding of the deed and examination of evidence of sending the deed The obstacles in the guidance and supervision of PPAT in Payakumbuh City are that there are no operational standards to carry out guidance and supervision of PPAT, lack of Human Resources (HR) / employees, both in terms of quality and quantity of employees, and the unavailability of the budget for the implementation of coaching and supervision of PPAT in the DIPA (List of Budget Implementers) of the Payakumbuh City Land Office.
\end{abstract}

Kata Kunci: Pembinaan, Pengawasan, Pejabat, Akta Tanah

\section{PENDAHULUAN}

Pasal 5 dan 6 Peraturan Pemerintah No. 24 Tahun 1997 tentang Pendaftaran Tanah menyatakan bahwa penyelenggara pendaftaran tanah adalah Badan Pertanahan Nasional. Pelaksanaan pendaftaran tanah dilakukan oleh Kepala Kantor Pertanahan yang ada disetiap kabupaten dan kota. Adapun tujuan pendaftaran tanah adalah (Boedi Harsono, 2008:519):

1. Untuk Memberikan Kepastian Hukum dan Perlingungan Hukum Kepada Pemegang hak atas suatu bidang tanah, satuan rumah susun dan hak-hak lain yang terdaftar agar dengan mudah dapat membuktikan dirinya sebagai pemegang hak yang bersangkutan. 
2. Untuk menyediakan informasi kepada pihak-pihak yang berkepentingan termasuk pemerintah agar dengan mudah dapat membperoleh data yang diperlukan dalam mengadakan perbuatan hukum mengenai bidang-bidang tanah dan satua-satuan rumah susun yang sudah terdaftar.

3. Untuk terselenggaranya Tertib Administrasi pertanahan.

Penyelenggaraan pendaftaran tanah di daerah dilaksanakan oleh Kepala Kantor Pertanahan, dibantu oleh Pejabat Pembuat Akta Tanah (PPAT) dan pejabat lain yang ditugaskan untuk melaksanakan kegiatan-kegiatan tertentu. Pejabat Pembuat Akta Tanah ini diangkat dan diberhentikan oleh Menteri. Pasal 1 angka 1 Peraturan Pemerintah No. 37 Tahun 1998 tentang Peraturan Jabatan Pejabat Pembuat Akta Tanah, disebutkan bahwa PPAT adalah pejabat umum yang diberi kewenangan untuk membuat akta-akta otentik mengenai perbuatan hukum tertentu mengenai hak atas tanah atau hak milik atas satuan rumah susun.

PPAT mempunyai tugas pokok melaksanakan sebagian tugas pendaftaran tanah dengan membuat akta sebagai bukti telah dilakukannya perbuatan hukum tertentu mengenai hak atas tanah atau hak milik satuan rumah susun, yang akan dijadikan dasar untuk perubahan data pendaftaran tanah. Perbuatan hukum yang dimaksud diatas adalah sebagai berikut:

1. Jual beli;

2. Tukar menukar;

3. Hibah;

4. pemasukan ke dalam perusahaan

5. Pembagian hak bersama;

6. Pemberian hak guna banguanan/hak pakai atas tanah hak milik;

7. Pemberian hak tanggungan

8. Pemberian kuasa memberikan hak tanggungan.

Dalam melaksanakan tugasnya dan prakteknya dilapangan ditemukan beberapa PPAT melakukan pelanggaran terhadap aturan-aturan yang telah ditetapkan. Seperti Dalam pembuatan akta PPAT tidak mempergunakan bentuk, isi dan cara pembuatan akta yang telah ditentukan oleh peraturan, tidak dihadiri oleh para pihak atau kuasanya dan saksi, PPAT tidak membacakan akta yang dibuatnya kepada para pihak dan menjelaskan maksud, dan isi akta serta prosedur pendaftarannya sesuai ketentuan yang berlaku, PPAT terlambat 
untuk mendaftarkan akta yang telah dibuatnya ke Kantor Pertanahan setempat, tidak menyampaikan laporan bulanan mengenai akta yang di buatnya.

Dengan adanya beberapa pelanggaran-pelanggaran yang dilakukan oleh PPAT maka perlu adanya pembinaan dan pengawasan terhadap PPAT. Pembinaan dan pengawasan PPAT diatur dalam Peraturan Menteri Agraria dan Tata Ruang/Kepala Badan Pertanahan Nasional No. 2 Tahun 2018 tentang Pembinaan dan Pengawasan Pejabat Pembuat Akta Tanah.

Di dalam menjalankan jabatannya PPAT dituntut untuk teliti, cermat, tertib dan memahami peraturan-peraturan terkait dengan pertanahan. Kondisi tersebut sebagai tuntutan yang realistis terkait dengan fungsi dan kewenangannya sebagai pejabat umum yang ditunjuk oleh Undang-Undang. Namun, dalam menjalankan jabatannya PPAT dimukgkinkan melakukan kesalahan baik secara administratif maupun secara yuridis. Sehingga PPAT sebagai pejabat umum dalam menjalankan jabatannya tidak lepas dari pembinaan dan pengawasan Badan Pertanahan Nasional sebagai lembaga yang mendapatkan kewenangan dari negara di bidang pertanahan.

Pembinaan dan Pengawasan yang dilakukan oleh Kantor Pertanahan terhadap para PPAT, juga dilaksanakan oleh Kantor Pertanahan Kota Payakumbuh. Sebagaimana diatur dalam Pasal 4 Peraturan Menteri Agraria dan Tata Ruang/Kepala Badan Pertanahan Nasional No. 2 Tahun 2018 tentang Pembinaan dan Pengawasan Pejabat Pembuat Akta Tanah yang menyatakan bahwa :

1. Pembinaan dan pengawasan terhadap PPAT dilakukan oleh Menteri.

2. Pembinaan dan pengawasan sebagaimana dimaksud pada ayat (1) didaerah dilakukan oleh Kepala Kantor Wilayah BPN dan Kepala Kantor Pertanahan.

Namun, ternyata dalam pelaksanaan pembinaan dan pengawasan terhadap PPAT, Kepala Kantor Pertanahan Kota Payakumbuh belum mengacu ke Peraturan Menteri Agraria dan Tata Ruang/Kepala Badan Pertanahan Nasional No. 2 Tahun 2018 tentang Pembinaan dan Pengawasan Pejabat Pembuat Akta Tanah. Hal ini disebabkan karena kurangnya perhatian kepala kantor untuk melakukan pembinaan dan pengawasan terhadap PPAT.

Pada prinsipnya pembinaan dan pengawasan Kantor Pertanahan Kota Payakumbuh terhadap para PPAT harus merujuk kepada peraturan yang mengatur tentang pembinaan 
dan pengawasan PPAT, dilakukan dengan prinsip berkesinambungan dan konsisten, dengan tujuan utama mengawasi PPAT di dalam menjalankan tugasnya agar selalu berpegang teguh kepada peraturan-peraturan yang ada.

Begitu besarnya peran Badan Pertanahan Nasional untuk mengoreksi, mengawasi dan membimbing kinerja dari para PPAT agar tidak menimbulkan kerugian dan kesalahan maka fungsi dari Badan Pertanahan Nasional tersebut jelas diatur di dalam peraturan pemerintah tentang PPAT dan peraturan pelaksanaannya. Fungsi pembinaan dan pengawasan yang dilaksanakan oleh Kantor Pertanahan Kota/Kabupaten terhadap PPAT dilakukan dengan ruang lingkup yang tidak hanya diatur oleh peraturan sebagaimana yang telah disebutkan diatas. Lebih dari itu dalam prakteknya cakupan/ruang lingkup pengawasan dan pembinaan dapat lebih luas bergantung pada kebijakan Kantor Pertanahan dan situasi yang ada dari setiap daerah.

Berdasarkan latar belakang pemikiran diatas, maka permasalahan yang dibahas dalam tulisan ilmiah ini adalah sebagai berikut :

1. Bagaimanakah pelaksanaan pembinaan dan pengawasan terhadap pejabat pembuat akta tanah dalam pendaftaran hak atas tanah di Kota Payakumbuh ?

2. Apa saja kendala dalam pelaksanaan pembinaan dan pengawasan terhadap pejabat pembuat akta tanah dalam pendaftaran hak atas tanah di Kota Payakumbuh ?

\section{METODE PENELITIAN}

Penelitian ini termasuk dalam spesifikasi deskriptif analisis dengan metode pendekatan yuridis normatif yang didukung oleh pendekatan yuridis empiris. Data yang digunakan dalam penelitian ini adalah data sekunder sebagai data utama dan data primer sebagai pendukung, yang dikumpulkan melalui studi kepustakaan dan studi lapangan dengan teknik wawancara. Data tersebut kemudian dianalisis secara kualitatif dan disajikan dalam bentuk deskriptif kualitatif.

\section{HASIL PENELITIAN DAN PEMBAHASAN}

Pelaksanaan Pembinaan dan Pengawasan Terhadap Pejabat Pembuat Akta Tanah dalam Pendaftaran Hak Atas Tanah di Kantor Pertanahan Kota Payakumbuh.

Pada kantor pertanahan seksi yang memiliki tugas dan fungsi untuk membina Pejabat Pembuat Akta Tanah adalah Seksi Hubungan Hukum Pertanahan. Fungsi tersebut 
dijalankan oleh subseksi Pemeliharaan Data Hak Tanah dan Pembinaan PPAT. Setelah keluarnya Peraturan Menteri Agraria dan Tata Ruang/Kepala Badan Pertanahan Nasional Nomor 2 Tahun 2018 tentang Pembinaan dan Pengawasan Pejabat Pembuat Akta Tanah, sesuai dengan Pasal 4 ayat (2) bahwa Pembinaan dan Pengawasan PPAT di daerah dilakukan oleh Kepala Kantor Pertanahan. Dalam melaksanakan pembinaan dan pengawasan PPAT di daerah ini maka dibentuklah Majelis Pembina dan Pengawas Pejabat Pembuat Akta Tanah Daerah atau disingkat dengan MPPD.

Dalam rangka pelaksanaan pembinaan dan pengawasan PPAT di Kota Payakumbuh dilaksanakan secara tidak langsung yang hanya dilakukan di kantor pertanahan. Walaupun hal tersebut sudah sesuai dengan peraturan perundang-undangan yang berlaku namun hasil yang diperoleh dari pembinaan dan pengawasan ini belum maksimal, sebab pembinaan yang dilakukan hanya sebatas sosialisasi peraturan prundang-undangan yang berkaitan dengan pelaksanaan tugas PPAT, pembuatan akta PPAT, laporan bulanan, pembuatan buku daftar akta dan penjilidan akta. Seharusnya, selain kantor pertanahan melakukan pembinaan dan pengawasan kepada PPAT di lakukan di kantor pertanahan, pembinaan dan pengawasan PPAT juga dilakukan dengan cara mengunjungi atau mendatangi kantor PPAT yang ada di Kota Payakumbuh. Namun hal ini belum bisa terlaksana karena keterbatasan sumber daya manusia, anggaran dan waktu.

Pembinaan yang dilakukan oleh Kepala Kantor Badan Pertanahan Nasional Kota Payakumbuh selama ini belum maksimal disebabkan pembinaan hanya dilakukan di kantor pertanahan, itu hanya sebatas pembuatan akta PPAT dan laporan bulanan. Pembinaan kepada Pejabat Pembuat Akta Tanah yang di lakukan selama ini adalah menyampaikan dalam pembuatan akta. Pembinaan dan pengawasan selama ini kepada PPAT dengan memberikan arahan dan petunjuk teknis dalam perkembangan pembuatan akta, pembuatan buku daftar akta, pembuatan laporan bulanan sesuai dengan Peraturan Kepala Badan pertanahan Nasional Nomor 1 Tahun 2006 dan ketentuan pelaksana Peraturan Jabatan Pejabat Pembuat Akta Tanah Nomor 24 Tahun 2016. Selama ini pembinaan dan pengawasan dilakukan pada waktu mendaftarkan hak atas tanah ataupun peralihan ke kantor Badan Pertanahan Nasional disebabkan apabila ada persyaratan matril dan formil yang masih kurang dan memberikan arahan kepada PPAT. 
Dari uraian diatas peneliti menyimpulkan bahwa pelaksanaan pembinaan dan pengawasan yang dilaksanakan oleh pejabat Badan Pertanahan Nasional khususnya Kantor Pertanahan Kota Payakumbuh yang diberi tugas dalam hal pembinaan pembuatan akta, laporan bulanan, penjilidan akta yang dilaksanakan tidak maksimal disebabkan masih ada Pejabat Pembuat Akta Tanah hanya dibina sewaktu pendaftaran hak saja dan pelaksanan dilakukan di kantor pertanahan. Menurut Peneliti pembinaan terhadap Pejabat Pembuat Akta Tanah tidak cukup hanya dilakukan di kantor pertanahan saja, karena masih banyak penyimpangan yang dilakukan oleh Pejabat Pembuat Akta Tanah, oleh karena itu pembinaan dan pengawasan seharusnya dilakukan juga dengan cara mengunjungi kantor PPAT sehingga hasil yang diperoleh dalam pembinaan dan pengawasan terhadap PPAT lebih maksimal.

Adapun Pembinaan dan Pengawasan Pejabat Pembuat Akta Tanah yang dilakukan di Kantor Pertanahan Kota Payakumbuh adalah :

\section{Pembinaan dan Pengawasan dalam Pembuatan Akta}

Dalam hal pembuatan akta PPAT, ada berbagai perkembangan dalam pengaturan mengenai bentuknya. Adapun payung hukum pengaturan dari bentuk akta PPAT dari dulu hingga sekarang yakni :

a. Peraturan Menteri Agraria Nomor 11 Tahun 1961 tentang Bentuk Akta (PMA 11/1961)

b. Peraturan Menteri Negara Agraria/Kepala Badan Pertanahan Nasional Nomor 3 Tahun 1997 tentang Ketentuan Pelaksanaan Peraturan Pemerintah Nomor 24 Tahun 1997 tentang Pendaftaran Tanah (PMNA/KBPN No. 3 Tahun 1997).

c. Peraturan Kepala Badan Pertanahan Nasional Nomor 8 Tahun 2012 tentang Perubahan Atas Peraturan Menteri Negara Agraria/Kepala Badan Pertanahan Nasional Nomor 3 Tahun 1997 tentang Ketentuan Pelaksanaan Peraturan Pemerintah Nomor 24 Tahun 1997 tentang Pendaftaran Tanah (Perkaban No. 8 Tahun 2012).

Adapun pembinaan yang dilakukan oleh Kantor Pertanahan Kota Payakumbh secara tidak langsung terhadap Pejabat Pembuat Akta Tanah dengan cara memeriksa akta yang akan didaftarkan oleh PPAT. Apabila akta tersebut tidak sesuai dengan ketentuan yang ada maka akta serta berkas permohonan tersebut dikembalikan kepada PPAT untuk diperbaiki. 


\section{Pembinaan dan Pengawasan dalam Pembuatan Laporan Bulanan}

Laporan bulanan diambil dari daftar akta yang dibuat setiap bulannya oleh Pejabat Pembuat Akta Tanah yang bersangkutan. Laporan bulanan dibuat untuk mencocokkan data yang ada di kantor pertanahan dengan data yang terdapat di kantor Pejabat Pembuat Akta Tanah. Laporan bulanan sangat erat hubungannya dengan Kewajiban Pembayaran Pajak Penghasilan dari Pengalihan Hak atas Tanah dan Bangunan. PPAT mempunyai kewajiban menyampaikan laporan bulanan mengenai akta yang dibuatnya kepada Kepala Kantor Pertanahan, Kepala Kantor Wilayah dan Kepala Kantor Pajak Bumi dan Bangunan setempat paling lambat tanggal 10 bulan berikutnya.

Kantor Pertanahan Kota Payakumbuh melakukan pembinaan dan pengawasan pembuatan laporan bulanan kepada PPAT. Laporan bulanan PPAT di rekap setiap bulannya dan dari rekapan tersebut dapat diketahui siapa yang menyampaikan laporan bulanan dan siapa yang tidak menyampaikan laporan bulanan. Bagi PPAT yang tidak menyampaikan laporan bulanan tersebut, dilakukan pembinaan dengan cara langsung memberitahukan dan menegur PPAT yang bersangkutan.

\section{Pembinaan dan Pengawasan Melalui Pemeriksaan Buku Daftar Akta}

Kepala Kantor Pertanahan melakukan pengawasan kepada PPAT melalui pemeriksaan buku daftar akta. Cara pengisian buku daftar akta ini diatur dalam Pasal 56 dan 57 Peraturan Kepala Badan Pertanahan Nasional Nomor 1 tahun 2006 tentang Ketentuan pelaksanaan dari Peraturan Pemerintah Nomor 37 Tahun 1998 tentang Peraturan Jabatan Pejabat Pembuat Akta Tanah. Pejabat Kantor Pertanah Kota Payakumbuh belum melakukan pemeriksaan terhadap buku daftar akta PPAT secara langsung ke Kantor PPAT, tetapi kantor pertanahan tetap melakukan pembinaan dengan cara mengingatkan kepada PPAT untuk tetap membuat buku daftar akta tersebut.

Kantor Pertanahan Kota Payakumbuh belum melakukan pemeriksaan buku daftar akta Pejabat Pembuat Akta Tanah, namun kepada PPAT tetap diberi pembinaan untuk tetap membuat buku daftar akta. Dalam pemeriksaan buku daftar akta masih ada ditemukan PPAT yang tidak mengisi buku daftar akta setiap harinya. Dengan adanya temuan ini pejabat kantor pertanahan memberikan penjelasan dan peringatan kepada PPAT untuk tidak lagi membuat hal seperti itu. 


\section{Pembinaan dan Pengawasan Melalui Pemeriksaan Hasil Penjilidan Akta}

Pengawasan Pejabat Pembuat Akta Tanah juga dilakukan dalam bentuk pemeriksaan pada hasil penjilidan akta. Penjilidan akta dilakukan oleh Pejabat Pembuat Akta Tanah untuk memudahkan pencarian akta perbuatan hukum yang dilakukan oleh klien karena pada sampul penjilidan akta dituliskan nomor, bulan dan tahun pembuatan akta. Selanjutnya Tata cara penjilidan akta dan warkah pendukung akta diatur dalam pasal 59 dan 60 Peraturan Kepala Badan Pertanahan Nasional Nomor 1 tahun 2006 tentang Ketentuan pelaksanaan dari Peraturan Pemerintah Nomor 37 Tahun 1998 tentang Peraturan Jabatan Pejabat Pembuat Akta Tanah. Pejabat Kantor Pertanahan Kota Payakumbuh belum melakukan pemeriksaan terhadap hasil penjilidan akta PPAT secara langsung ke Kantor PPAT, tetapi pejabat kantor pertanahan tetap melakukan pembinaan dengan cara mengingatkan kepada PPAT untuk tetap melakukan penjilidan akta tersebut sesuai dengan peraturan yang berlaku.

Kantor Pertanahan Kota Payakumbuh belum melakukan pemeriksaan hasil penjilidan akta pada Pejabat Pembuat Akta Tanah. Hal ini harus diperhatikan oleh Badan Pertanahan Nasional selaku pejabat yang melakukan pembinaan dan pengawasan terhadap PPAT.

\section{Pembinaan dan Pengawasan Melalui Pemeriksaan Bukti-Bukti Pengiriman Akta} (Tanda Terima dari Kantor Pertanahan).

Pengawasan terhadap Pejabat Pembuat Akta Tanah juga dilakukan dalam bentuk pemeriksaan bukti-bukti pengiriman akta ke kantor pertanahan. Dalam Pasal 61 Peraturan Kepala Badan Pertanahan Nasional Nomor 1 tahun 2006 tentang Ketentuan Pelaksanaan dari Peraturan Pemerintah Nomor 37 Tahun 1998 tentang Peraturan Jabatan Pejabat Pembuat Akta Tanah menegaskan bahwa Pejabat Pembuat Akta Tanah wajib menyampaikan akta Pejabat Pembuat Akta Tanah dan dokumen-dokumen lain yang diperlukan untuk keperluan pendaftaran akta perbuatan hukum yang dibuatnya kepada Kepala Kantor Pertanahan paling lambat 7 (tujuh) hari kerja sejak ditandatangani akta yang bersangkutan. Apabila terjadi pelanggaran terhadap ketentuan tersebut maka merupakan pelanggaran administratif. Pejabat Kantor Pertanahan Kota Payakumbuh memberikan tanda terima kepada PPAT yang mendaftarkan aktanya ke kantor pertanahan. Pada waktu pendaftaran dan pemeriksaan berkas pada petugas loket 
akan terlihat mana akta yang terlambat pendaftrannya. Dan kepada PPAT tersebut hanya diberi teguran lisan.

Dari hasil penelitian di lapangan menunjukkan bahwa pejabat kantor pertanahan telah melakukan pemeriksaan bukti-bukti pengiriman akta melalui tanda terima yang diberikan oleh kantor pertanahan, yang dapat dilihat dalam penyampaian berkas secara langsung ke Kantor Pertanahan Kota Payakumbuh.

Dari uraian diatas peneliti menyimpulkan bahwa pihak-pihak yang berwenang melakukan pembinaan dan pengawasan terhadap PPAT dalam melaksanakan jabatannya adalah Badan Pertanahan Nasional. Adapun peranan Badan Pertanahan Nasional dalam hal ini adalah memberikan pembinaan dan pengawasan terhadap PPAT agar dalam melaksanakan jabatannya sesuai dengan peraturan perundang-undangan yang berlaku. Dengan adanya pembinaan dan pengawasan terhadap PPAT dapat diketahui ada tidaknya pelanggaran yang dilakukan oleh PPAT dalam pelaksanaan jabatannya sebagai PPAT.

Dalam upaya menegakkan fungsi pembinaan dan pengawasan Pejabat Pembuat Akta Tanah maka tindak lanjut dari pembinaan dan pengawasan tersebut memegang peranan yang sangat penting. Pembinaan dan pengawasan yang tidak diikuti oleh tindak lanjutnya maka hanya akan merupakan suatu hal yang sia-sia dan akan merusak citra pembinaan dan pengawasan itu sendiri.

Dalam Peraturan Pemerintah Nomor 24 Tahun 2016 tentang Peraturan Jabatan Pejabat Pembuat Akta Tanah dan Peraturan Kepala Badan Pertanahan Nasional Nomor 1 Tahun 2006 tentang Ketentuan Pelaksanaan Peraturan Pemerintah Nomor 24 Tahun 2016 perubahan Peraturan Pemerintaah Nomor 37 Tahun1998 tentang Peraturan Jabatan Pejabat Pembuat Akta Tanah menegaskan bahwa sanksi yang dapat dijatuhkan oleh badan pertanahan kepada Pejabat Pembuat Akta Tanah adalah sanksi administratif mulai dari teguran lisan sampai dengan pemberhentian dengan tidak hormat dari jabatannya. Penjatuhan sanksi diterapkan apabila ada Pejabat Pembuat Akta Tanah yang melakukan pelanggaran baik pelanggaran ringan maupun pelanggaran berat.

Menurut Pasal 13 ayat (1) Peraturan Menteri Agraria dan Tata Ruang/ Kepala Badan pertanahan Nasional Nomor 2 Tahun 2018 tentang Pembinaan dan Pengawasan 
PPAT, Pemberian sanksi yang dikenakan terhadap PPAT yang melakukan pelanggaran dapat berupa :

a. Teguran tertulis

b. Pemberhentian sementara

c. Pemberhentian dengan hormat

d. Pemberhentian dengan tidak hormat

Pasal 14 ayat (1) menyatakan bahwa Pemberian sanksi terhadap pelanggaran yang dilakukan oleh PPAT berupa teguran tertulis dilakukan oleh Kepala Kantor Pertanahan.

Dari hasil penelitian di lapangan, Kepala Kantor Pertanahan Kota Payakumbuh tidak pernah menjatuhkan sanksi berupa teguran tertulis sebagaimana yang diatur dalam peraturan perundang-undangan mengenai pelanggaran yang dilakukan oleh Pejabat Pembuat Akta Tanah. Pejabat hanya melakukan teguran lisan terhadap Pejabat Pembuat Akta Tanah yang bersangkutan meskipun itu termasuk pelanggaran berat. Hal ini mengakibatkan pelanggaran-pelanggaran tersebut akan terus berlangsung hingga saat ini, apabila tidak dijatuhi sanksi.

\section{Kendala-Kendala Dalam Pembinaan dan Pengawasan Terhadap Pejabat Pembuat Akta Tanah Dalam Pendaftaran Hak Atas Tanah di Kantor Pertanahan Kota Payakumbuh.}

1. Belum adanya Standar Operasional pelaksanaan pembinaan dan pengawasan terhadap Pejabat Pembuat Akta Tanah di Kantor Pertanahan Kota Payakumbuh

Pada kantor pertanahan Kota Payakumbuh belum terdapat standar operasional dalam pelaksanaan pembinaan dan pengawasan Pejabat Pembuat Akta Tanah. Pembinaan dan pengawasan dilakukan dengan adanya temuan kesalahan dalam pendaftaran tanah. Menurut peneliti, standar operasional pelaksanaan harus dibuat terlebih dahulu sebelum melaksanakan pembinaan dan pengawasan terhadap PPAT karena untuk mencapai sebuah praktek pembinaan dan pengawasan yang ideal, pada prinsipnya pembinaan dan pengawasan sangat bergantung kepada bagaimana pembinaan dan pengawasan dijalankan.

2. Sumber Daya Manusia

Permasalahan mengenai sumber daya pejabat pada kantor pertanahan bukan hanya kesulitan untuk memperoleh tenaga-tenaga ahli untuk melakukan pembinaan dan pengawasan kepada Pejabat Pembuat Akta Tanah, akan tetapi secara umum kualitas pejabat pada badan pertanahan yang melakukan pembinaan dan pengawasan tersebut 
masih cukup banyak yang kurang memenuhi persyaratan sebagai tenaga pembina dan pengawas.

Menurut peneliti penyebab utamanya adalah karena pengertian dan kesadaran pembinaan dan pengawasan belum dipahami dengan baik oleh para pejabat pada kantor pertanahan yang melakukan pembinaan dan pengawasan. Kualitas pejabat yang melakukan pembinaan dan pengawasan masih perlu ditingkatkan dan untuk itu perlu perhatiaan dari para pejabat pimpinan pada Badan Pertanahan Nasional yang berwenang menentukan kebijakan dalam menempatkan pejabat pada kantor pertanahan dalam melaksanakan pembinaan dan pengawasan.

3. Anggaran untuk Pelaksanaan Pembinaaan dan Pengawasan PPAT.

DIPA (Daftar Isian Pelaksana Anggaran) Kantor Pertanahan Kota Payakumbuh untuk tahun 2018 dan beberapa tahun sebelumnya tidak ada dana yang dialokasikan untuk pembinaan dan pengawasan PPAT. Sehingga para pejabat Kantor Pertanahan Kota Payakumbuh tidak dapat melaksanakan pembinaan dan pengawasan terhadap PPAT dengan cara mengunjungi Kantor PPAT. Dan hanya melakukan pembinaan dan pengawasan di kantor pertanahan saja, bahkan pada waktu PPAT mengajukan/ mendaftarkan berkas permohonan ke Kantor Pertanahan. Hal ini tidak dapat memberikan hasil yang optimal dalam melakukan pembinaan dan pengawasan kepada PPAT yang ada di Kota Payakumbuh.

\section{PENUTUP}

Berdasarkan hasil penelitian dan pembahasan serta analisis maka dapat disimpulkan hal-hal sebagai berikut :

1. Pelaksanaan pembinaan dan pengawasan terhadap Pejabat Pembuat Akta Tanah dalam pendaftaran hak atas tanah di Kota Payakumbuh, dilakukan oleh Badan Pertanahan Nasional melalui sosialisasi peraturan-peraturan yang berhubungan dengan ke-PPAT-an, pembuatan akta, pembuatan laporan bulanan, pemeriksaan buku daftar akta, pemeriksaan hasil penjilidan akta dan pemeriksaan bukti-bukti pengiriman akta. Pelaksanan pembinaan dan pengawasan hanya dilakukan di kantor pertanahan saja, sewaktau pendaftaran hak dilakukan oleh Pajabat Pembuat Akta Tanah. 
2. Kendala dalam pelaksanaan pembinaan dan pengawasan terhadap Pejabat Pembuat Akta Tanah di Kota Payakumbuh adalah kendala yuridis dan non yuridis. Kendala yuridis yaitu belum adanya standar operasional untuk melaksanakan pembinaan dan pengawasan terhadap PPAT. Kenadal non yuridis yaitu kurangnya Sumber Daya Manusia (SDM) baik itu dari segi kualitas maupun kuantitas pegawai sehingga memungkinkan keterbatasan kemampuan Kantor Pertanahan Kota Payakumbuh untuk melakukan pembinaan dan pengawasan terhadap PPAT di Kota Payakumbuh, dan tidak tersedianya Anggaran untuk pelaksanaan pembinaan dan pengawasan terhadap PPAT dalam DIPA (Daftar Isian Pelaksana Anggaran) Kantor Pertanahan Kota Payakumbuh.

\section{DAFTAR PUSTAKA}

\section{Buku Taks:}

Boedi Harsono, Hukum Agraria Indonesia, Himpunan Peraturan-Peraturan Hukum Tanah, Peraturan Pemerintah Nomor 24 tahun 1997 tentang Pendaftaran Tanah, Djambatan, Jakarta, 2008

\section{Peraturan Perundang-Undangan:}

Peraturan Pemerintah Nomor 24 Tahun 1997 tentang Pendaftaran Tanah.

Peraturan Pemerintah Nomor 37 Tahun 1998 Tentang Peraturan Jabatan Pembuat Akta Tanah

Peraturan Pemerintah Nomor 24 Tahun 2016 tentang Perubahan Atas Peraturan Pemerintah Nomor 37 Tahun 1998 tentang Peraturan Jabatan Pejabat Pembuat Akta Tanah

Peraturan Menteri Negara Agraria/Kepala Badan Pertanahan Nasional Nomor 1 Tahun 2006 tentang Ketentuan Pelaksanaan Peraturan Pemerintah Nomor 37 Tahun 1998 tentang Jabatan Pejabat Pembuat Akta Tanah.

Peraturan Menteri Agraria dan Tata ruang/ Kepala Badan Pertanahan Nasional Nomor 2 Tahun 2018 tentang Pembinaan dan Pengawasan Pejabat Pembuat Akta Tanah. 